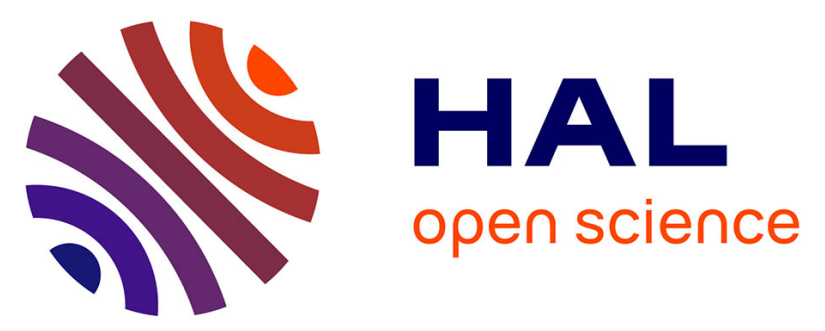

\title{
Cerebrospinal fluid pharmacokinetics of ceftaroline in neurosurgical patients with external ventricular drain
}

Pascal Chavanet, Alexia Chauzy, Nadine Defrance, Abdelouaïd Nadji, Jean-Christophe Combes, William Couet, Lionel Piroth

\section{To cite this version:}

Pascal Chavanet, Alexia Chauzy, Nadine Defrance, Abdelouaïd Nadji, Jean-Christophe Combes, et al.. Cerebrospinal fluid pharmacokinetics of ceftaroline in neurosurgical patients with external ventricular drain. the 28th European Congress of Clinical Microbiology and Infectious Diseases (ECCMID), Apr 2018, Madrid, Spain. hal-02528340

\section{HAL Id: hal-02528340 \\ https://hal.science/hal-02528340}

Submitted on 1 Apr 2020

HAL is a multi-disciplinary open access archive for the deposit and dissemination of scientific research documents, whether they are published or not. The documents may come from teaching and research institutions in France or abroad, or from public or private research centers.
L'archive ouverte pluridisciplinaire HAL, est destinée au dépôt et à la diffusion de documents scientifiques de niveau recherche, publiés ou non, émanant des établissements d'enseignement et de recherche français ou étrangers, des laboratoires publics ou privés. 


\section{P2223 Cerebrospinal fluid pharmacokinetics of ceftaroline in neurosurgical patients with external ventricular drain}

Chavanet P 1; Chauzy A 2; Defrance N ${ }^{3}$; Nadji A ${ }^{3}$; Combes JC ${ }^{3}$; Couet W 2; Piroth L 1

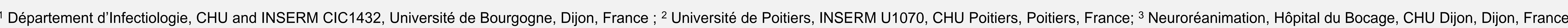

\section{INTRODUCTION}

- Ceftaroline is a broad spectrum cephalosporin with activity against drugresistant bacteria, including strains of methicillin-resistant Staphylococcus aureus (MRSA) [1,2], and could be attractive for prevention or treatment of bacterial post-neurosurgical meningitis. However, only few data are available concerning its meningeal concentrations [3].

- The aim of this study was to assess the distribution of ceftaroline into the cerebrospinal fluid (CSF) in intensive care unit (ICU) patients with an external ventricular drain (EVD) at risk or with suspicion of meningitis.

\section{METHODS}

Ethics

- This study was approved by the local ethics committee (Comite de Protection des Personnes Est-I, \# 2014-004138-25) and authorised as a clinical study by the national drugs administration (Agence Nationale de Sécurité du Médicament).

Study design

Nine patients with suspected post neurosurgical meningitis and hospitalized in the neurosurgery intensive care unit of Dijon University Hospital were included in the analysis.

- Patients received a single $600 \mathrm{mg}$ dose of ceftaroline as a one-hour intravenous infusion.

- Plasma and CSF samples were collected before and 0.5, 1, 3, 6, 12 and 24 hours after the end of the infusion. CSF sampling was performed via the EVD system.

- All samples were assayed at Covance laboratory by LC-MS/MS.

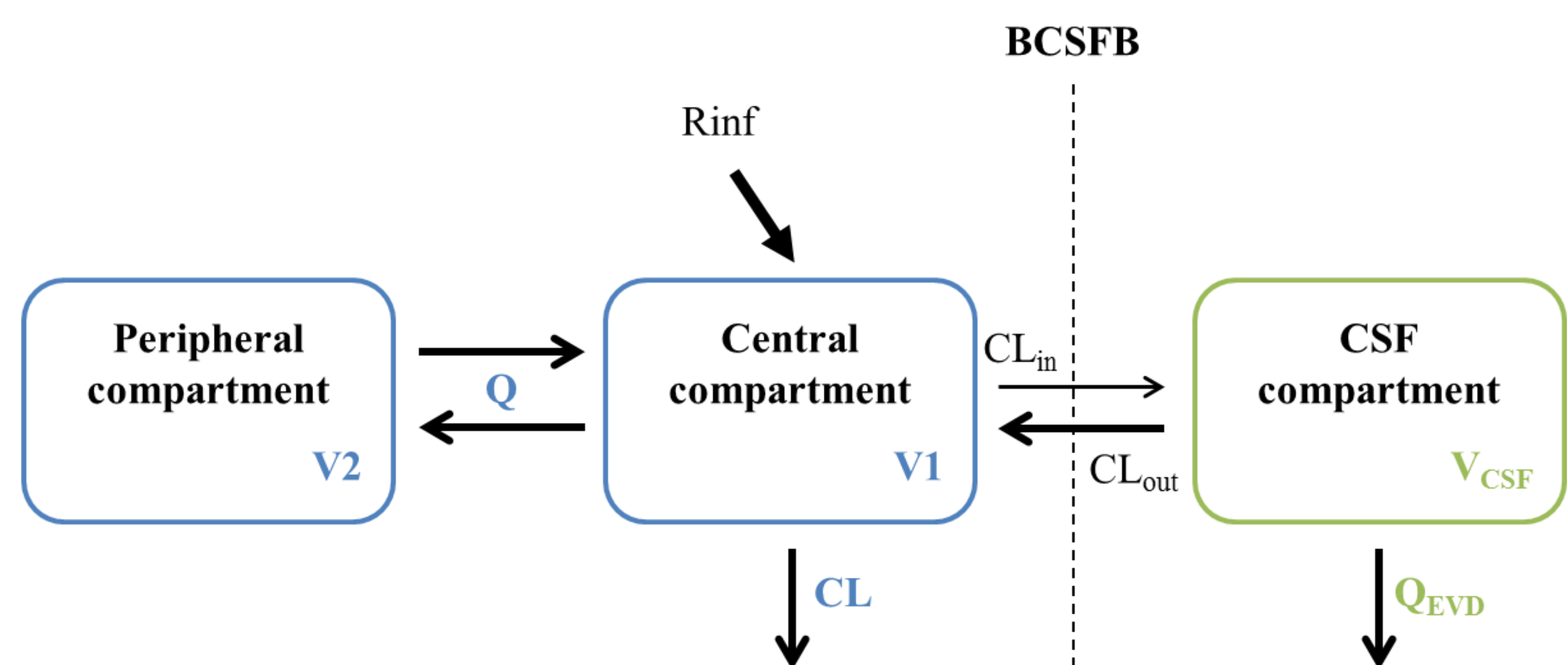

figure 1. Schematic representation of ceftaroline final PK model used to describe total plasm nd unbound CSF concen
Population pharmacokinetic analysis

Ceftaroline concentrations in plasma and CSF were analyzed using the nonlinear mixed effects modeling approach in NONMEM software version 7.4.

A two-steps compartmental PK analysis was conducted:

1) ceftaroline plasma data were first analyzed,

2) plasma parameters estimated and corrected for protein binding of $20 \%$ [2] were fixed to fit unbound CSF concentrations.

The influence of various patient characteristics on the parameter estimates were investigated.

\section{RESULTS}

Observed peak concentrations in CSF $(0.22 \pm 0.17 \mu \mathrm{g} / \mathrm{mL})$ were much lower than plasma peak concentrations $(18.29 \pm 3.33 \mu \mathrm{g} / \mathrm{mL})$ and EUCAST clinical MIC breakpoint for susceptibility to ceftaroline among $S$. aureus isolates $(2 \mu \mathrm{g} / \mathrm{mL})$ [ 4$]$ (Figure 2).

- Total plasma concentrations of ceftaroline versus time were best fitted by a twocompartment model with first-order elimination. After the inclusion of CSF data the model was expanded and a three-compartment model was used to describe all ceftaroline concentrations simultaneously (Figure 1).

- Elimination of ceftaroline from the CSF via the EVD was taken into account by fixing the flow rate of the EVD (QEVD) for each patient to its experimental value.

Table 1. Typical estimates for ceftaroline pharmacokinetic parameters

\begin{tabular}{|c|c|c|}
\hline Parameter & Estimate (RSE\%) & IIV CV\% (RSE\%) \\
\hline \multicolumn{3}{|c|}{$C L=C L_{p o p}{ }^{*} \operatorname{EXP}\left[C L C r_{\text {coo }}{ }^{*}(C L C r-6.9)\right]$} \\
\hline $\mathrm{CL}_{\mathrm{pop}}(\mathrm{L} / \mathrm{h})$ & $11.3(5)$ & $15.9(44)$ \\
\hline $\mathrm{CLCr}_{\mathrm{cov}}$ & $0.0047(23)$ & \\
\hline \multicolumn{3}{|l|}{$V 1=V 1_{p o p}{ }^{*}(B W / 79)$} \\
\hline $\mathrm{V} 1_{\mathrm{pop}}(\mathrm{L})$ & $28.4(10)$ & $16.6(102)$ \\
\hline$Q(L / h)$ & $6.06(20)$ & \\
\hline V2 (L) & $11.0(12)$ & \\
\hline \multicolumn{3}{|c|}{$C L i n=C L i n_{p o p} *\left[(G L Y / 3.9)^{* *} G L Y_{c o v}\right]$} \\
\hline $\mathrm{Clin}_{\mathrm{pop}}(\mathrm{mL} / \mathrm{h})$ & $\begin{array}{l}1.39(17) \\
-3.0(10)\end{array}$ & $54.0(50)^{\text {a }}$ \\
\hline CLout (mL/h) & $14.8(18)$ & $54.0(50)^{\mathrm{a}}$ \\
\hline$V_{C S F}(L)$ & $0.15^{b}$ & \\
\hline
\end{tabular}

"A same IIV was estimated for Clin and Clout.

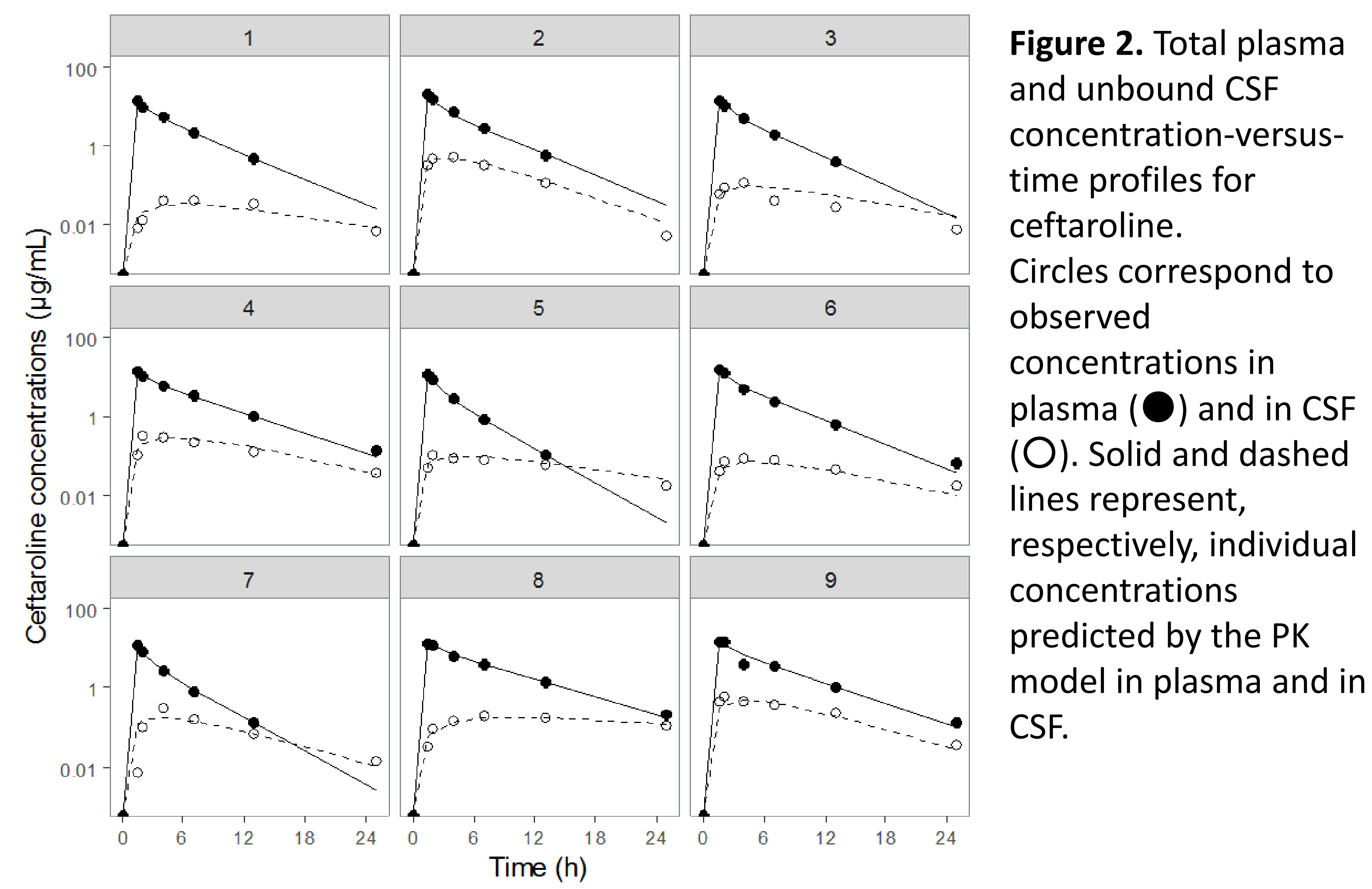

- The bidirectional passage across the blood cerebrospinal fluid barrier (BCSFB) was characterized by a clearance into the CSF (CLin) and a clearance out of the CSF (CLOut) (Figure 1). Estimated CLin was much lower characterizes ceftaroline distribution within the CSF, equal to $9.4 \%$.

- A negative correlation between glycorrhachia and CLin was identified indicating that the diffusion of ceftaroline into the CSF was inversely related to the CSF glucose levels (Table 1, Figure 3). Mean glycorrhachia of 4.39 $\mathrm{mmol} / \mathrm{L}$ suggested that patients of the present study presented only a slight inflammation of their meninges.

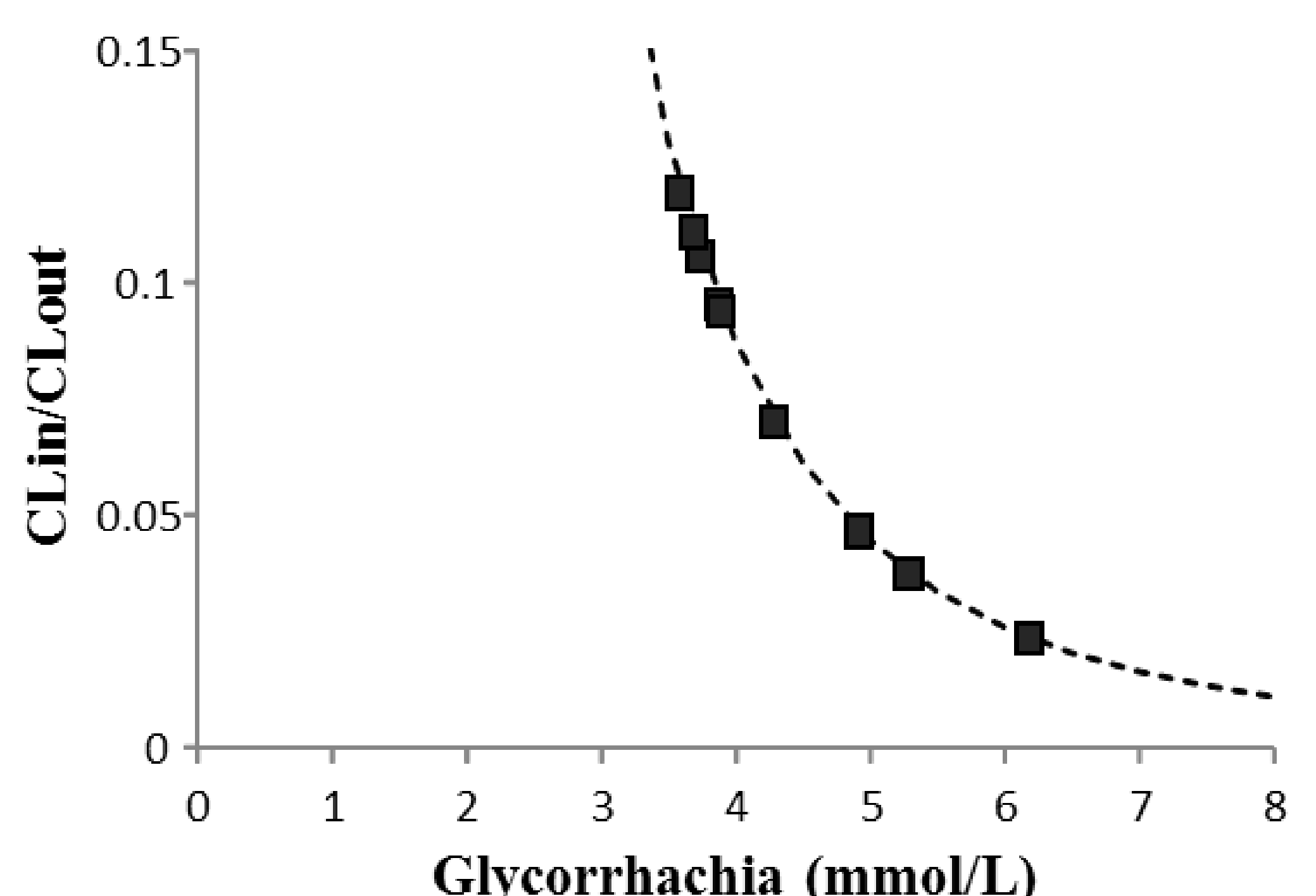

igure 3. Correlation between CSF (CLin/CLout ratio) and slycorrhachia. Squares correspond to observed CLin/CLout ratio and dashed line presents mean CLin/CLout ratio redicted by the model .

\section{CONCLUSIONS}

Following a single infusion of $600 \mathrm{mg}$, ceftaroline penetration into the meninges is limited, with a CSF exposure equal to only $9.4 \%$ of systemic exposure on average. CSF concentrations are then too low for ensuring prophylactic protection or therapeutic effect against most pathogens with MICs between 1 and 2 mg/L.

- However, the model suggests that in case of meningitis with a low glycorrhachia $(<1.9 \mathrm{mmol} / \mathrm{L})$ [5], ceftaroline CSF exposure would be much greater

- Additional studies aiming at assessing the distribution following multiple higher doses are needed.

REFERENCES

[1] Sader HS, et al., Antimicrob Agents Chemother, 2013, [2] Jorgenson MR, et al., Ann Pharmacother, 2011. [3] Stein GE, et al., Surg Infect, 2015. [4] EUCAST. Version 7.1, 2017. http://www.eucast.org. [4] de Lange ECM, J Pharmacokinet Pharmacodyn, 2013. [5] Khatib U, et al., J Infect, 2017. 